\title{
OBSERVATION ON RESPONSIVE OCV VARIATION OF ZINC-AIR CELL WITH RELATIVE HUMIDITY CONTENT
}

\author{
HANiSAH MANSHOR ${ }^{1}$, RAIHAN OTHMAN ${ }^{2}$, ANIS NURASHIKIN NORDIN ${ }^{3}$ \\ MOHd HaNAFi ANI ${ }^{1}$ ANd Hens SAPUTRA ${ }^{4}$ \\ ${ }^{I}$ Department of Manufacturing and Materials Engineering, \\ ${ }^{2}$ Department of Science in Engineering, \\ ${ }^{3}$ Department of Electrical and Computer Engineering, \\ Faculty of Engineering, International Islamic University Malaysia, \\ P.O. Box 10, 50728 Kuala Lumpur, Malaysia. \\ ${ }^{4}$ Pusat Teknologi Industri Proses \\ Badan Pengkajian dan Penerapan Teknologi (BPPT) \\ Jl. M.H. Thamrin No. 8, Jakarta 10340, Indonesia. \\ raihan@iium.edu.my
}

\begin{abstract}
Zinc/MCM-41/air cell, in its dry form without the electrolyte, demonstrates humidity sensing property. A good linear correlation between the cell's open circuit voltage (OCV) and the relative humidity content is observed. The system possesses the potential to be developed into a low cost microhumidity sensor. An ultra thin cell of thickness not more than $40 \mu \mathrm{m}$ has been fabricated and its use as a humidity sensor is substantiated.
\end{abstract}

ABSTRAK: Sel zinc/MCM-41/udara, dalam keadaan kering tanpa elektrolit, menunjukkan sifat pencirian kelembapan. Voltan litar terbuka sel didapati menunjukkan korelasi linear yang baik terhadap kandungan kelembapan relatif. Sistem ini berpotensi untuk dibangunkan menjadi penciri kelembapan mikro yang murah. Sel yang amat nipis dengan ketebalan tidak melebihi $40 \mu \mathrm{m}$ telah difabrikasi and kegunaannya sebagai penciri kelembapan dibuktikan.

KEYWORDS: zinc-air cell; MCM-41 membrane; humidity sensor; microsensor

\section{INTRODUCTION}

The development of low cost micro-humidity sensors requires specific considerations of microfabrication technology and processing techniques due to the complexities associated with humidity measurement. The relatively complex post-processing techniques employed to integrate the humidity sensitive material within the microstructure of the humidity sensor contributed towards high cost of such devices [1-2].

In this paper, we report a preliminary observation on humidity sensing behaviour of zinc-air microbattery of less than $40 \mu \mathrm{m}$ thick. The open circuit voltage (OCV) of the electrochemical cell is found responsive with the ambient humidity variation. Most importantly the construction of the microbattery merely requires the fabrication of a threelayered structure i.e. zinc, MCM-41 and carbon, which is highly compatible with microelectronics fabrication. Interestingly, no addition of caustic electrolyte, which is commonly the case for zinc-air system, is needed. These characteristics show promising prospects for the zinc-air microsystem to be further explored and developed as a novel microhumidity sensor. 


\section{EXPERIMENTAL METHOD}

\subsection{Zinc-air Microbattery Components and Construction}

An electrochemical cell in principle consists of an anode and a cathode in an ionic conducting medium or electrolyte. A physical contact between the anode and cathode is prevented by placing an ionic exchange membrane or separator between them. Zinc-air cell belongs to the metal-air electrochemical system in which an electropositive metal element is coupled with the electronegative oxygen of the ambient air. Normally a carbonbased air electrode is used as the oxygen reaction site. In this work, zinc served as the anode, an inorganic MCM-41 membrane as the separator, and a carbon layer functioned as the air cathode. Details of characterization of MCM-41 as a separator material can be referred to the work of Saputra et al. [3].

Zinc was prepared from an electrodeposition technique from an acidic chloride bath (2 M zinc chloride electrolyte). A two-electrode configuration was used. Zinc was deposited onto copper foil $(10 \mu \mathrm{m})$ at a constant current of $100 \mathrm{~mA}$ for 10 minutes. An EcoChemie (The Netherland) potentiostat/galvanostat (PGSTAT302N, AUTOLAB) was used.

MCM-41 material was prepared from a parent solution consisted of cetyltrimethyl ammonium bromide (CTAB), tetraethylorthosilicate (TEOS), hydrochloric acid ( $\mathrm{HCl})$, distilled water $\left(\mathrm{H}_{2} \mathrm{O}\right)$ and ethanol $\left(\mathrm{C}_{2} \mathrm{H}_{5} \mathrm{OH}\right)$, with molar ratio formulation of $0.05 \mathrm{CTAB}$, 1.0 TEOS, $0.5 \mathrm{HCl}, 25 \mathrm{C}_{2} \mathrm{H}_{5} \mathrm{OH}$ and $75 \mathrm{H}_{2} \mathrm{O}$. CTAB served as the cationic surfactant while TEOS was the silica source. The mixture of parent solution was stirred at about 200 $\mathrm{rpm}$ at $30^{\circ} \mathrm{C}$ for 1 hour. The electrodeposited zinc layer was then coated by MCM-41 membrane by spin coating technique (Cee ${ }^{\circledR}$ 200X Precision Spin Coater). The spin speed was set to $2000 \mathrm{rpm}$ for duration of 10 seconds. Finally CTAB template was removed from MCM-41 pore structure by leaching with EtOH. This template removal process is named solvent extraction, which is reported as an alternative to heat treatment process [4]. This method was adapted because heat treatment process will cause the zinc electrodeposits to be oxidized.

Finally carbon paste was applied onto MCM-41 coated zinc anode as the air cathode. The carbon paste consisted of carbon particulate suspension (SPI-CHEM ${ }^{\mathrm{TM}}$ ) in ethanol. Normally catalytic compound such as manganese oxide is mixed with the air cathode as the oxygen reduction reaction is rate-limiting. However, in the present work no catalyst was added to the carbon paste as the fabricated cell was not required to deliver discharge current. Once carbon paste was applied, the zinc-air cell ready to be tested. We did not incorporate any electrolyte into the fabricated cell. The cell was left to operate in its dry form.

Figure 1 illustrates the schematic diagram of the fabricated zinc-air microbattery and the photograph is shown in Fig. 2. The area of the zinc electrodeposits was approximately $1 \mathrm{~cm}^{2}$. The distinct appearance of the copper foil of Fig. 2 was due to MCM-41 coating i.e. the uncoated area appeared brighter.

\subsection{Material Characterization}

The structural formation of MCM-41 was verified using small angle X-ray diffraction analysis $\left(\mathrm{Cu} \mathrm{K} \alpha\right.$ radiation, $2 \theta$ range of 1.5 - $10^{\circ}$, scan speed of $2 \%$ minute $)$. The microstructure images of zinc electrodeposits and MCM-41 membrane were observed using Scanning Electron Microscope (JSM 5600) and Feld-Emmision Scanning Electron Microscope (FE-SEM) (JED-2100, JEOL Co. Ltd.) respectively. 


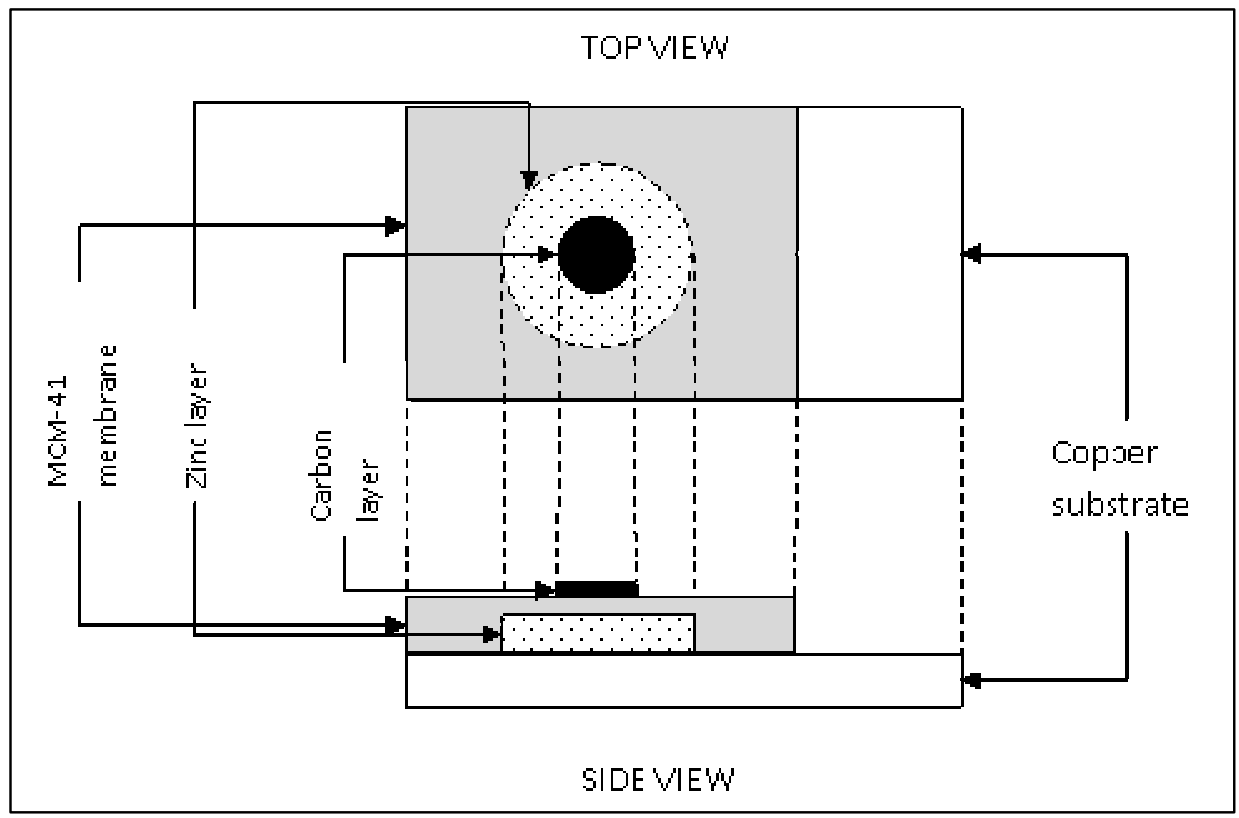

Fig. 1: Schematic illustration of zinc-air cell and its components.

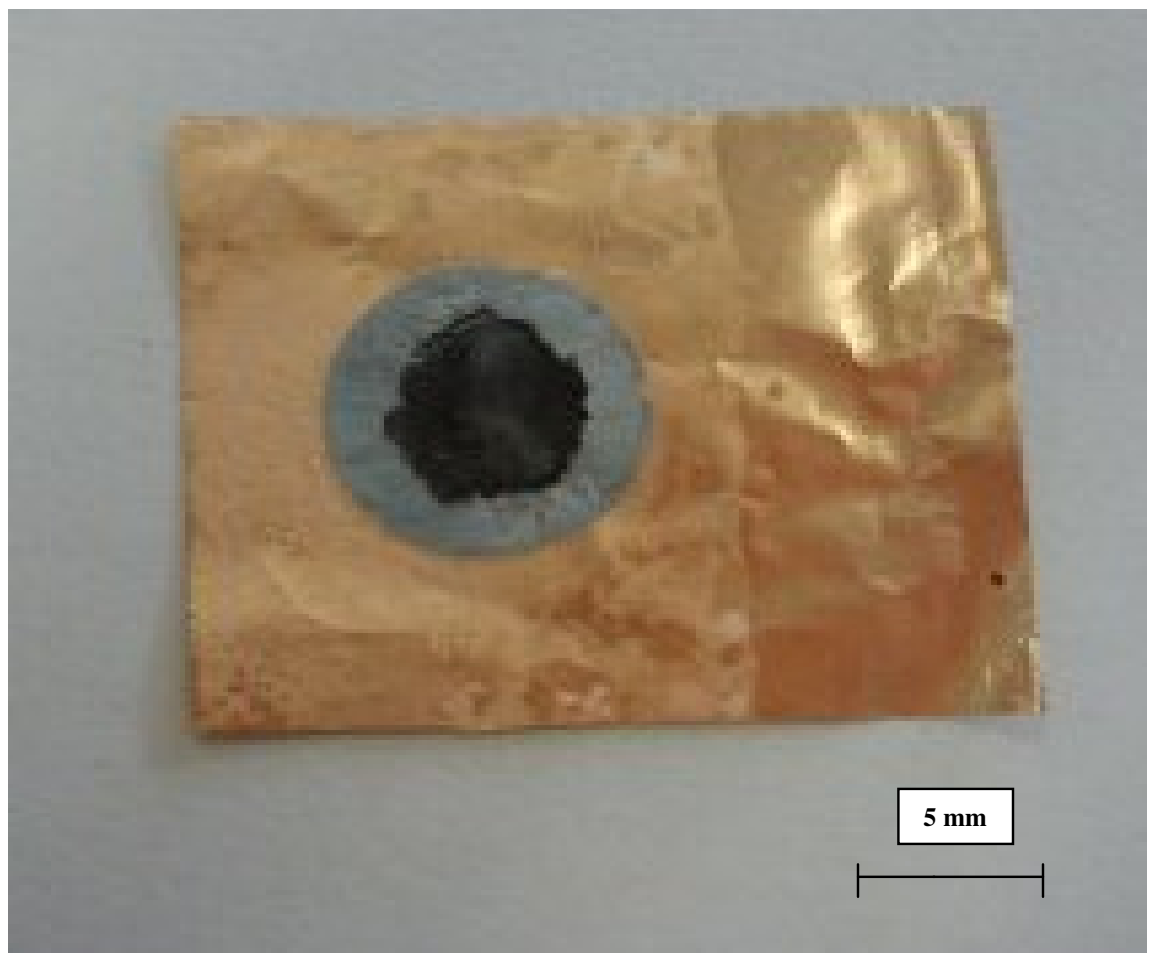

Fig. 2: Photograph of the fabricated ultra thin cell as microhumidity sensor.

\subsection{OCV Measurement and Relative Humidity Monitoring}

OCV measurement of the zinc-air cell was conducted by Eco Chemie (The Netherland) Autolab Galvanostat/Potentiostat in open ambient surrounding. A commercial digital humidity sensor (Lascar Humidity EL-USB-2) was placed in close proximity to the cell. Both measurements were performed simultaneously for 19 hours. 


\section{RESULTS AND DISCUSSION}

XRD analysis of Fig. 3 confirms the structural formation of MCM-41 material. Its hexagonal lattice structure is characterized by the dominant (100) peak and followed by three small diffraction peaks, as listed in Table 1 [5-8]. MCM-41 material belongs to a group of mesoporous materials known as M41S. This class of material is characterized by its regular arrays of tunable uniform channels with large surface area. MCM-41 materials possess the high specific surface area and pore volume of about $1000 \mathrm{~m}^{2} \mathrm{~g}^{-1}$ and $1 \mathrm{~cm}^{3} \mathrm{~g}^{-1}$ respectively, very narrow pore size distribution $(\sim 2 \mathrm{~nm})$ and very good thermal stability i.e. up to $900^{\circ} \mathrm{C}[5,9,10]$.

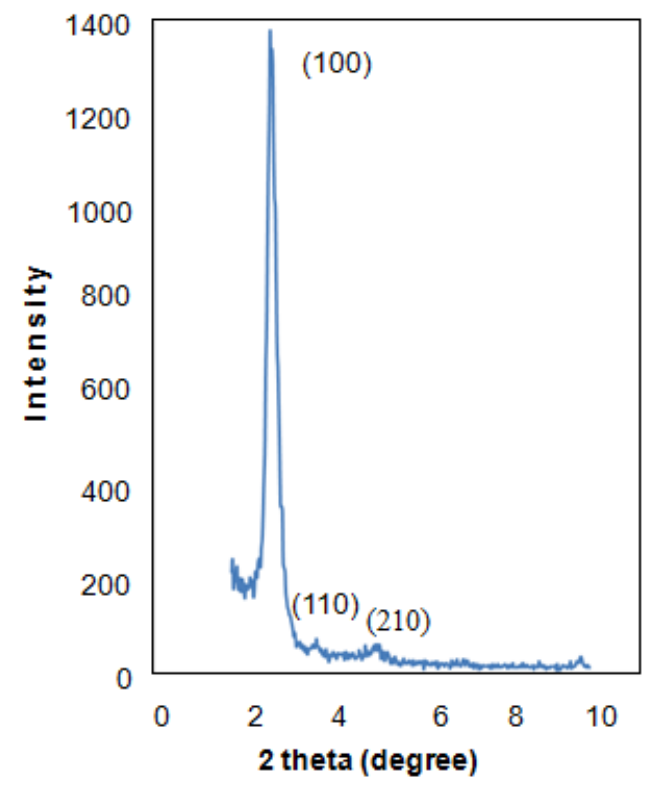

Fig. 3: XRD pattern of the as-synthesized MCM-41 material.

Table 1 Characteristic of MCM-41 X-ray diffractogram.

\begin{tabular}{cc}
\hline hkl & d / ̊ \\
100 & 39.8 \\
110 & 22.9 \\
200 & 19.8 \\
210 & 14.9 \\
\hline
\end{tabular}

Figure 4 displays the SEM image of the electrodeposited zinc layer. The SEM image was focussed at the boundary between the plated area and bare copper substrate in order to estimate the thickness. The thickness of the zinc layer was estimated around $30 \mu \mathrm{m}$. The zinc layer was in the form of granular deposits and the deposits seemed to be smooth and even. But most importantly the electrodeposits were non-dendritic. Dendritic or tree-like deposits will cause premature electrochemical cell failure due to internal short-circuiting [11]. 


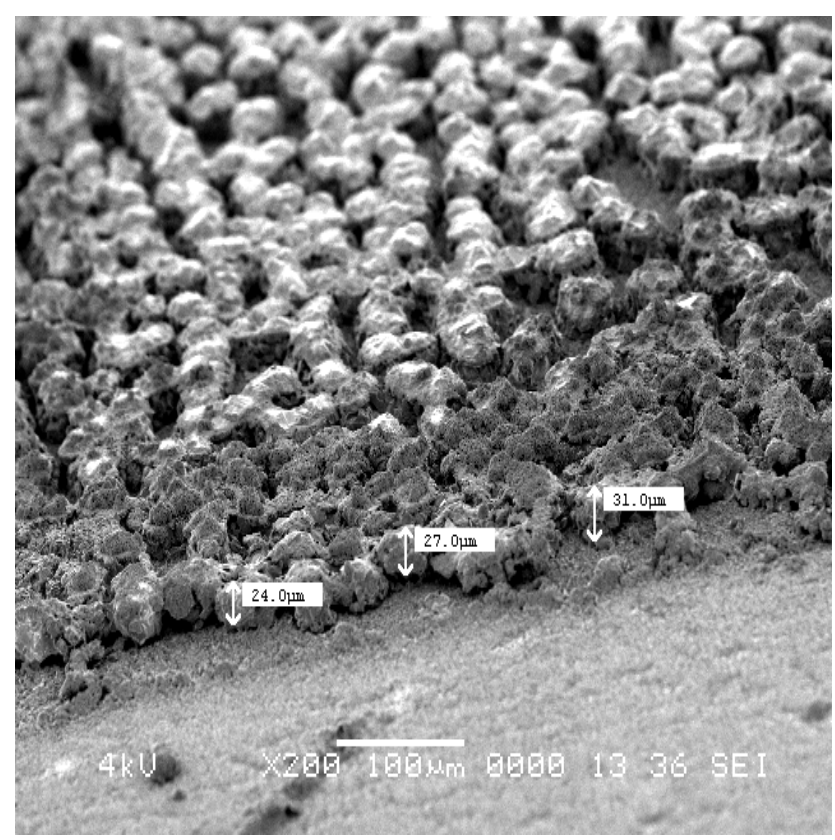

Fig. 4: SEM micrograph of electrodeposited zinc layer.

Figure 5 shows FE-SEM image of MCM-41 membrane encapsulating the zinc electrodeposits at 100,000 magnifications. The micrograph reveals the coarse, high surface area characteristics of the material.

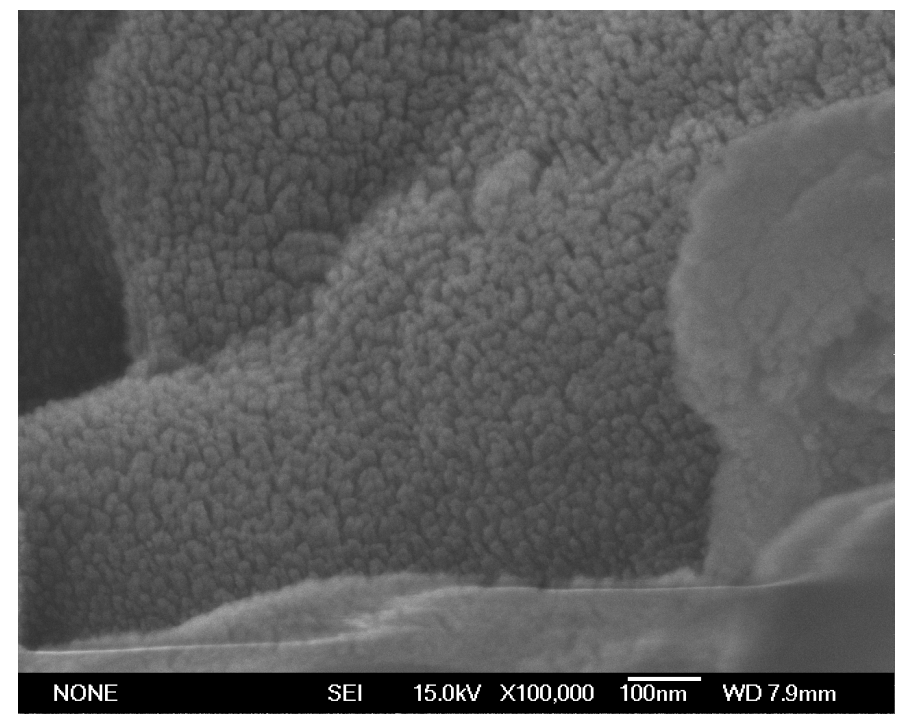

Fig. 5: FE-SEM micrograph of MCM-41 membrane.

We noticed that the zinc/MCM-41/air cell in its dry form registered changing OCV readings over time. Since the as-synthesized MCM-41 material is hydrophilic in nature, we suspected the variation in the OCV could be related to the changing humidity content of the ambient air. Figure 6 highlights the measurement of relative humidity of our laboratory over a period of 19 hours and the corresponding variation of the OCV of the dry zinc/MCM-41/air cell. Both profiles were similar, thus suggesting a direct correlation 
between the OCV values of the cell with relative humidity content. The curve for OCV variation is smoother since the potentiostat/galvanostat was able to record a five and a half digits voltage value. On the other hand, the digital humidity sensor could only measure the smallest variation of $0.5 \%$. Fig. 7 is the correlation plot between the cell's OCV and the relative humidity content. The linear trend of the plot further supports that a correlation between them could be established. As mentioned earlier, the use of a more accurate digital humidity sensor could substantiate a more significant correlation.

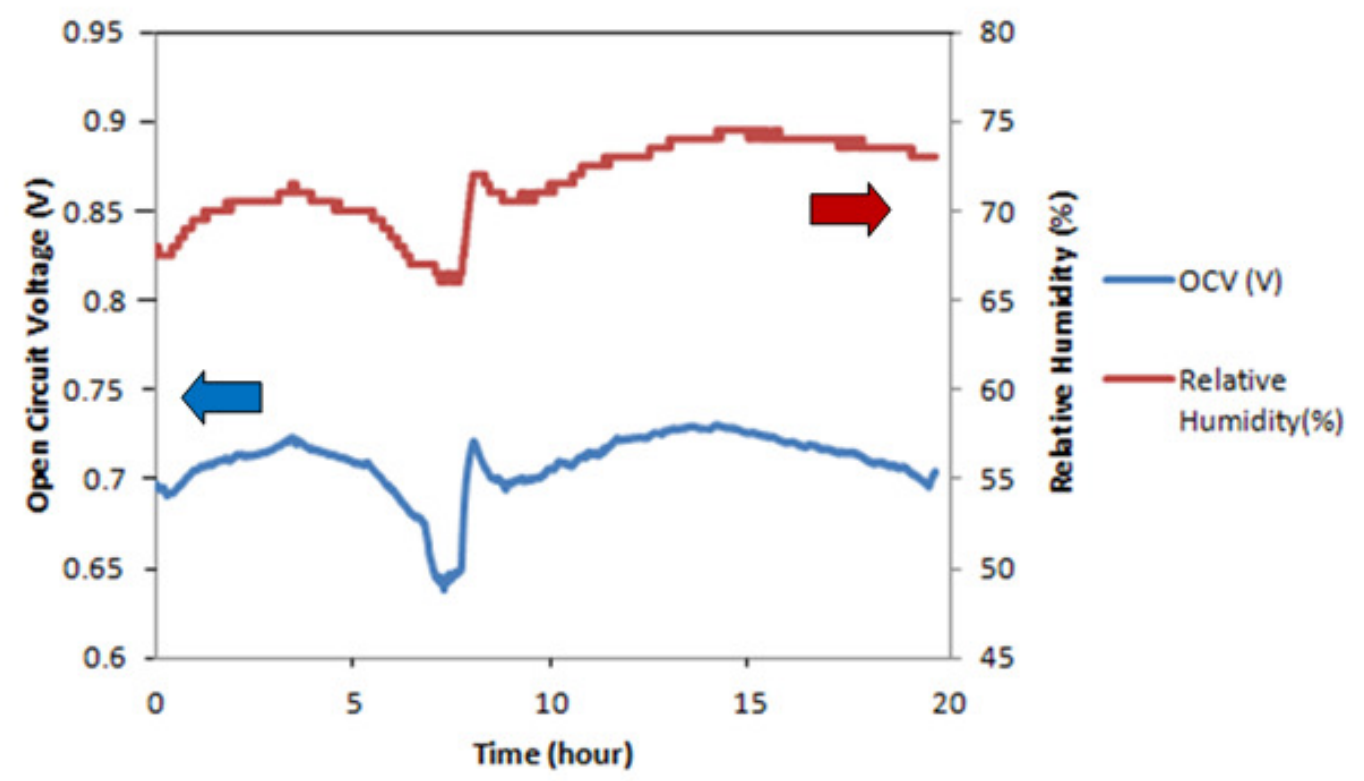

Fig. 6: OCV responds of cell as compared to relative humidity readings from digital humidity sensor.

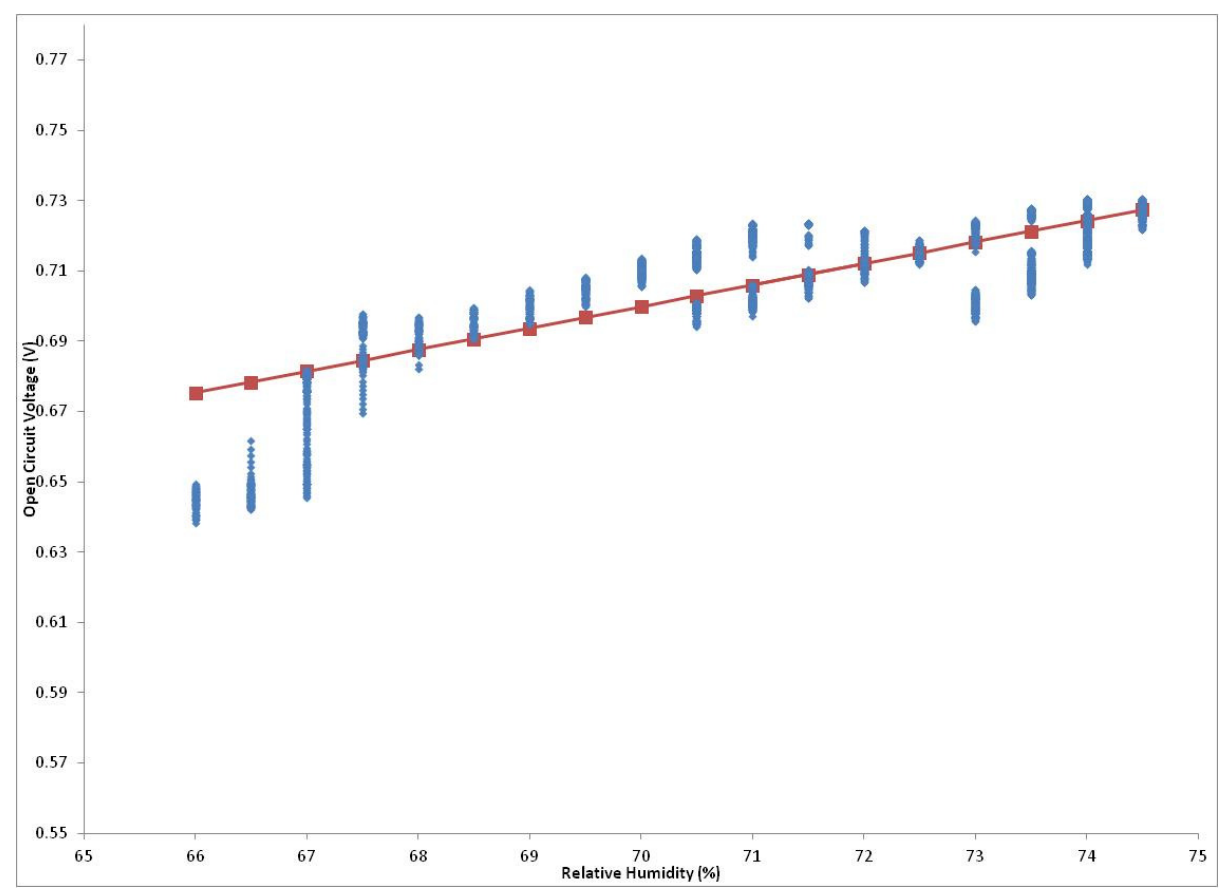

Fig. 7: Correlation between the cells's OCV and the relative humidity content. 
We attributed the observed humidity sensing behaviour of zinc/MCM-41/air cell to the hydrophilic property of MCM-41material $[12,13]$. MCM-41 surface structure is covered with silanol groups $(\mathrm{Si}-\mathrm{OH})$ formed during the synthesis of the material. While these groups serve as hydration site, the mesoporous phase of MCM-41 makes the structure accessible for water physisorption from the surrounding moisture [14, 15]. Consequently, the adsorption-desorption of water molecules from zinc/MCM-41/air cell affected its OCV thus enables the system to be utilized as a novel micro humidity sensor.

\section{CONCLUSION}

A zinc/MCM-41/air cell possessed a humidity sensing property. We have fabricated an ultra thin cell of thickness not more than $40 \mu \mathrm{m}$ and demonstrated its use as relative humidity sensor. The cell consists merely of three thin layers of different materials and it's free from any corrosive electrolyte since the cell is utilized in the dry form. Hence its fabrication is very much compatible with microelectronics processing and highly potential to be further developed as a low cost microhumidity sensor.

\section{ACKNOWLEDGEMENT}

The International Islamic University Malaysia funded this project through the Research Matching Grant Scheme (RMGS 09-09). The authors gratefully acknowledge the financial support.

\section{REFERENCES}

[1] H. Shibata, M. Ito, M. Asakursa, and K. Watanabe, "A digital hygrometer using a polyimide film relative humidity sensor". IEEE, Vol. 45, no. 2, 564-569, 1996.

[2] N. Yamazoe and Y. Shimizu, Humidity sensors: Principles and applications, Sensors and Actuators, 10 (1986) 379-398.

[3] H. Saputra, et al., "MCM-41 as a new separator material for electrochemical cell: Application in zinc-air system". Journal of Membrane Science 367, 152-157, 2011.

[4] A. Marcilla, et al., "Template removal in MCM-41 type materials by solvent extraction: Influence of the treatment on the textural properties of the material and the effect on its behaviour as catalyst for reducing tobacco smoking toxicity". Chemical Engineering Research and design, Vol. 89, 2330-2343, 2001.

[5] C. T. Kresge, M. E. Leonowicz, W. J. Roth, J. C. Vartuli and J. S. Beck, Ordered mesoporous molecular sieves synthesized by a liquid-crystal template mechanism, Nature 359 (1992) 710-712.

[6] G. Øye, J. Sjöblom, M. Stöcker, Synthesis, characterization and potential applications of new materials in the mesoporous range, Advances in Colloid and Interface Science. Elsevier 89 (2001) 439-466.

[7] Z. Bayram-Hahn, BA. Grimes1, AM. Lind1, R Skudas, KK. Unger1, A Galarneau, J Iapichella, F. Fajula, Pore structural characteristics, size exclusion properties and column performance of two mesoporous amorphous silicas and their pseudomorphically transformed MCM-41 type derivatives, J Sep Sci 30:18 (2007) 3089-3103.

[8] Q. Li, et al., "Synthesis and characterization of MCM-41-supported $\mathrm{Ba}_{2} \mathrm{SiO}_{4}$ base catalyst". Microporous and Mesoporous Materials 59, 105-111, 2003.

[9] J. S. Beck, J. C. Vartuli, W. J. Roth, M. E. Leonowicz, C. T. Kresge, K. D. Schmitt, C. T. W. Chu, D. H. Olson, E. W. Sheppard, A new family of mesoporous molecular 
IIUM Engineering Journal, Vol. 12, No. 5, 2011: Special Issue -1 on Science and Ethics in Engineering Manshor et al.

sieves prepared with liquid crystal templates, J. Am. Chem. Soc. 114:27 (1992) 10834-10843.

[10] R. Ryoo and S. Jun, "Improvement of hydrothermal stability of MCM-41using salt effects during the crystallization process". J. Phys. Chem. B 101, 317-320, 1997.

[11] S. Martirosyam, "Zinc electrode with reduced dendritic propagation". Journal of Power Sources Vol. 172, Issue 2, 984-987, 2007.

[12] P. J. Branton, et al., "Physisorption of argon, nitrogen and oxygen by MCM-41, a model mesoporous adsorbent". J. Chem. Soc. Faraday Trans. Vol. 90, no.19, 29652967, 1994.

[13] K. A. Northcott, et al., "The adsorption of divalent metal cations on mesoporous silicate MCM-41". Chemical Engineering Journal 157, 25-28, 2010.

[14] P. Innocenzi, et al., "Electrical and structural characterisation of mesoporous silica thin films as humidity sensors". Sensors and Actuators B 76, 299-303, 2001.

[15] A. Bearzotti, et al., "Relative humidity and alcohol sensors based on mesoporous silica thin films synthesised from block copolymers". Sensors and Actuators B 95, 107-110, 2003. 